\title{
Using the Educational Histories of Individuals to Complicate Standard Historical Narratives about Expanding Citizenship Rights and Opportunity
}

\section{Valinda W. Littlefield}

Course: History of Soutbern African American Education, 1865-Present (an upper-division course, crossed-listed between the Department of History, African American Studies, and the Institute for Southern Studies)

Institution: University of Soutb Carolina, Columbia

My History of Southern African American Education, 1865-Present class, a mid-level survey course, examines the history of education for African Americans in the South from Reconstruction to the twentyfirst century. It draws a variety of undergraduate students, as it is crosslisted with the College of Education, Department of History, African American Studies Program, and the Institute of Southern Studies. We examine issues of power and privilege, and the ways that race, ethnicity, gender, and socioeconomic status interact with educational opportunities and achievement. A major objective is to help students understand the ways in which public education in the United States was shaped by competing economic, political, and ideological interests; this focus includes learning the ways in which schools reinforced and reshaped the larger society. Another objective is to use local, state, and regional educational issues to provide a background for understanding the history of education as well as patterns, trends, and changes in the larger historical narrative.

To accomplish this task, I pair secondary sources, literary texts, and primary documents with outside-the-classroom learning, which includes oral interviews. Students then participate in an integrative learning experience based on stories of "schooling for democratic citizenship and schooling for second-class citizenship" in both historical and contemporary contexts. ${ }^{1}$

Valinda Littlefield is an associate professor in the Department of History and director of African American Studies in the College of Arts and Sciences at the University of South Carolina.

'James D. Anderson, The Education of Blacks in the South, 1860-1935 (Chapel Hill: University of North Carolina Press, 1988). 
My personal history deeply forms my approach to the course. I am a product of the South. Born in a small rural area of Durham, North Carolina, in the 1950s, I experienced segregation and desegregation. My experiences with my great-grandmother, grandmother, mother, father, aunts, uncles, and their friends as well as other relatives, white neighbors, and black teachers in my all-black school from first to eleventh grade shaped my understanding of race and my own identity. I learned at an early age that ordinary people lived very interesting lives. My African-American community's aspirations for future generations impacted me the most. For example, my immediate family encouraged me to "get an education," although only one uncle had graduated from high school. Teachers were active community members, whether they lived in the community of their students or not. They expected and demanded the best from me. ${ }^{2}$ These memories have shaped my dedication to, as well as my style of, teaching, both on the campus and beyond it. I approach teaching with an understanding of the influence of ordinary people on the future and try to instill in my students a love of understanding the past through the memories of elders. My hope is that this activity and knowledge gained will help them to develop skills to synthesize and formulate conclusions about current and potential issues of social justice and to become active participants in shaping access to education in the future.

After a brief introduction to the broader history of education in the United States, the rest of the course focuses on the South and is organized chronologically and by historical epochs (i.e., 1865 to the 1890 s to the 1920 s, etc.). This approach allows me to integrate the historical context beyond the realm of schooling as a way to dramatize what was happening for African Americans at any particular time. For example, 1865 to the 1890 s was a period that saw the rising tide of white supremacy and the horrors of terrorist acts against African Americans. During this time, many African Americans' expectations of equality rose due to progress in land ownership and literacy. By 1910, Southern African Americans owned 25 percent of Southern land compared to 3.8 percent in 1880 . Those in the state legislatures ushered in universal education laws while others formed education associations and built or organized schools in churches, lodges, and homes. Literacy rates rose to 50 percent from an estimated 5 percent to 10 percent before $1865 .^{3}$

\footnotetext{
${ }^{2}$ Several teachers drove approximately 80 miles round trip each school day. Yet they attended events in the community and often took students home with them on the weekends.

${ }^{3}$ Anderson, The Education of Blacks in the South; Grace Elizabeth Hale, Making Whiteness: The Culture of Segregation in the South, 1890-1940 (New York: Vintage Books, 1999), 9, 21; J. Gilbert, G. Sharp, and S. Felin, "The Loss and
} 
The period from the 1890 s to the early 1900 s, which historian Rayford Logan termed the "nadir of American race relations," was a second watershed period in African-American history, including educational history. ${ }^{4}$ If the first period was the rising tide of white supremacy, the second period can be considered the unrelenting waters of the fully entrenched Jim Crow era. Between 1890 and 1900, Mississippi, South Carolina, Louisiana, and North Carolina approved legislation disfranchising, in some cases, the majority of their population. It had hugely negative effects for African-American rights and access to education, particularly in Mississippi and South Carolina, where African Americans constituted a majority well into the 1920s. By 1908, Virginia, Alabama, Georgia, and Texas followed suit. Lynching and other forms of violence and intimidation increased during this period. A 1919 NAACP report found that 3,224 African Americans were lynched between 1889 and 1918, mostly in the South. Court cases such as Plessy v. Ferguson (1896) curtailed legal avenues for equality.

During this same period, however, the second Morrill Act (1890) provided federal funding for African-American higher education institutions. Individuals and organizations such as African-American women's clubs (a movement started in 1896), the Niagara Movement (established in 1905), and the NAACP (established in 1910) initiated strategies to continue the fight for equality. African Americans fought for access to high school education in cases such as Cumming $v$. Board of Education (1899). And Progressive Era programs such as the Rosenwald Schools, which were seeded by the Julius Rosenwald Fund but mainly funded and maintained by African Americans, resulted in thousands of schools for African-American students in fifteen Southern states.

The primary teaching objective in having students engage with these two historical periods is to help them understand and critically analyze two common themes they have studied in their standard American history courses. First, the African-American experience during these time periods dramatizes the contentious and bumpy path of expanding rights and opportunities for American citizens, such as access to education and economic progress. Second, African-American agency in initiating and maintaining reform for improving lives can be understood as a lens through which to understand broader reform movements like those of the Progressive Era.

\footnotetext{
Persistence of Black-Owned Farms and Farmland: A review of the Research Literature and Its Implications," Soutbern Rural Sociology 18, no. 2 (December 2002): 1-30; and Glenda Elizabeth Gilmore, "Somewhere in the Nadir of African American History, 1890-1920," in Freedom's Story, TeacherServe, National Humanities Center, http://nationalhumanitiescenter.org/tserve/freedom/1865-1917/essays/nadir.htm.

${ }^{4}$ Rayford W. Logan, The Betrayal of the Negro: From Rutberford B. Hayes to Woodrow Wilson (New York: Da Capo Press, 1997).
} 
Other questions also guide student learning and serve to complicate and complement these themes. Students must address such questions as: How does educational access based on racial and gender inequalities complicate the common theme in American history of expanding rights and opportunities for all citizens? How can political dissent from black, white, and other communities provide an understanding of "racial politics" during a period? What are some strategies used by African Americans to combat an oppressive system, and what are the risks? These questions ask students to understand the complexity of African-American educational history in its broader context.

To help students appreciate this complexity, I have found it important to assign literary selections along with historical texts and primary documents since students learn in many different ways. Throughout these multiple types of "cases," I provide as many venues to the learning process as possible. Literary selections allow students to imagine a place and time. How can one understand a historical period without reading the literature of that period? Primary documents also provide students with the opportunity to analyze and make arguments about a particular issue, place, and time. The combination of all three enhances students' ability to grasp complexities of the past and to understand why access to education does not perfectly fit into the common themes of opportunities and expanding rights for all American citizens.

For instance, when we engage with the period between 1865 and the 1890 s, I assign a chapter from James D. Anderson's The Education of Blacks in the South, 1860-1935 on freedmen and freedwomen and the quest for universal education in the South between 1860 and 1880 as a way for students to get a broad understanding of what was happening in terms of African-American education at the time. I also assign primary sources, including excerpts from the diary of Charlotte Forten, a Northern African-American woman who taught on St. Helena Island, South Carolina, during the Port Royal Experiment. ${ }^{5}$ Excerpts from the 1868 South Carolina Constitutional Convention Proceedings and the 1868 South Carolina Constitution are used as well as chapters from Pauli Murray's Proud Shoes and Sarah and Elizabeth Delany's Having Our Say. ${ }^{6}$

Together, these varied readings from different perspectives help students analyze the early struggles and initiatives for access to

${ }^{5}$ Charlotte Forten, "Life on the Sea Islands," Atlantic Montbly 13 (May 1864): 587-96, http://historymatters.gmu.edu/d/6517/; see also Ray Allen Billington, ed., $A$ Free Negro in the Slave Era: The Fournal of Charlotte Forten (New York: Collier, 1953), 158-85.

${ }^{6}$ Sarah L. Delany, A. Elizabeth Delany, and Amy Hill Hearth, Having Our Say: The Delany Sisters' First 100 Years (New York: Delta Books, 2007); and Pauli Murray, Proud Sboes: The Story of an American Family (Boston: Beacon Press, 1999). 
education by African Americans and personalizes that battle outlined by Anderson. In particular, the document by Forten demonstrates students' eagerness to learn and parents' willingness to make sacrifices so that their children could attend school. The 1868 South Carolina Constitutional Convention documents provide students with the arguments for compulsory education made by African-American politicians and the beginning of free public education for all citizens. The experiences of the Delany and Fitzgerald-Murray families point to the common themes often taught of expanding rights and opportunities as these families sought to maintain middle-class status and identified education as the way not only to make that a reality but to assist others in obtaining middle-class status.

I also use literary works as a way to provide students with an indepth understanding of social, economic, and political ideologies of a place and time, since fictional characters can provide insights into real lives. For the period of the 1890 s to the 1920 s, I pair a chapter from Leon Litwack's Trouble in Mind and W. E. B. Du Bois's "Of the Coming of John" from The Souls of Black Folk. ${ }^{7}$ Litwack's story of Charlie Holcombe and Du Bois's story of John have many similarities. Both the real-life Charlie and the fictional John grew up in a time where they "had to act a way just though everything was all right." Both evoke "the contradictions of black life and coming of age in the New Southinitial hopes and aspirations, the often heightened expectations, as well as the frustrations, the terrors, the tensions, the betrayals..." Both Charlie's and John's experiences allow students to feel, hear, smell, and see these contradictions through the plight of both men in their quest for an education. African Americans' battles with racial etiquette, definitions of one's place, humiliation, and indignities-all part of an oppressive system meant to keep them at the bottom-can allow for a better understanding of the everyday experiences of the masses in a particular place. Students are then able to understand one group's struggle to access education as well as analyze the potential complications and risks involved when they received that education.

Students also read "The Hampton Model" and "Education and the Race Problem" and examine primary documents for Plessy, Cumming, and the 1919 "South Carolina Petition." These readings and documents are used to engage students with understanding how and why

${ }^{7}$ Leon F. Litwack, Trouble in Mind: Black Southerners in the Age of Fim Crow (New York: Vintage, 1999); and W. E. B. Du Bois, The Souls of Black Folk (New York: Bedford/St. Martin's, 1997).

${ }^{8}$ Litwack, Trouble in Mind, 7.

${ }^{9}$ Anderson, "The Hampton Model of Normal School Industrial Education 18681915" and "Education and the Race Problem in the New South," in The Education of Blacks in the South, 33-109; and the 1919 "South Carolina Petition," Na- 
the U.S. educational system developed and embodied conflicting values, especially those based on race and Southern space. The readings prompt students to discuss how difference in class, access to power, political and material resources, as well as race, ethnicity, and gender have significantly shaped the history of public education. The documents also allow students to examine further strategies used by African Americans in their pursuit of self-determination and education.

In terms of how I use my class time to engage students with these topics and issues, I often break the students into groups and have them read documents together during class. I have found that this interaction often helps to encourage the quiet students to participate in-class discussions. In addition, my exams often require an analysis of political cartoons, songs, or poetry. Testing students using multiple sources provides me with a more balanced and comprehensive analysis of student performance.

The final assignment is a twelve- to fifteen-page paper. Students are required to pair their in-class readings and knowledge with primarysource research and oral interviews, two skills that many students are only beginning to learn. I scaffold these out-of-class experiences by hosting a session preparing for primary-source research at the South Caroliniana Library and by providing short readings on oral interview methodologies and filmed interviews that $I$ have done. Students then conduct mock interviews to ensure they are ready for the task. All potential interviewees once attended a now defunct African-American school, and students do preliminary research on the school and person before the interview.

Gathering the information and interviewing are cooperative components of the process since students conduct the interviews and preliminary research in pairs. Afterward, each student writes an individual paper about findings that are grounded in the other secondary, primary, and literary source knowledge gained in the course. They are encouraged to look for patterns or things that interested them from the interview based on their own classroom experience or personal interests. For example, if the interviewee discussed a vocational class that led to establishing a business, a student could place vocational education in historical context and then analyze what was sold or what service was provided to understand the story this particular business tells about a particular effort at a particular time and about a particular educational focus within the school. If an interviewee discussed extracurricular activities, such as a Latin club, chorus, or athletics, a student might focus

tional Humanities Center Resource Toolbox, http://nationalhumanitiescenter.org/pds/ maai3/protest/text1/petition1919.pdf. 
on such activities and use secondary documents to compare and contrast student experiences or opportunities for extracurricular activities at other schools.

After studying the history of education in the South, I hope that students are better equipped to ask complex questions pertaining to complex issues that can be directed to themselves, and current and future leaders. Historical knowledge gained in this class has provided students with multiple cases of educational reform efforts. How might that knowledge contribute to their understanding and proceed to question the reform efforts that parents, students, and educators face today? How might that knowledge allow them to analyze policies and motivate change in contemporary issues such as funding equity, zero-tolerance policies, charter schools, and vouchers, to name a few? For example, President Ronald Reagan argued that the educational system was ripe with low standards, lack of purpose, and a failure to strive for excellence. And while the federal government argued for educational reform, it scaled back its role in education and shifted the burden of reform to state and local authorities. So throughout the 1980s and 1990s, reform efforts such as zero-tolerance policies, privatization, vouchers, and less funding from the federal government became part of the landscape of schooling. I believe students can take what they have learned in my class in terms of the need to challenge inequality, interrogate, and triangulate sources, and be sensitive to issues of race, gender, and class and become better informed and active citizens in our democracy.

\title{
Reconstructing the Southern Landscape: The History of Education and the Struggle for Civil Rights in Charleston, South Carolina
}

\author{
Fon N. Hale
}

Course: Foundations of Education

Institution: College of Charleston

\footnotetext{
Jon Hale is an assistant professor of educational history at the College of Charleston in South Carolina. He would like to thank Nancy Beadie for the invitation to submit this piece and the other contributors for their insightful feedback and comments. Jon can be reached at halejn@cofc.edu.
} 